Portland State University

PDXScholar

Sociology Faculty Publications and

Presentations

Sociology

$12-1-2010$

\title{
Corporate Cooptation of Organic and Fair Trade Standards
}

\author{
Daniel Jaffee \\ Portland State University, jaffee@pdx.edu \\ Philip Howard \\ Michigan State University
}

Follow this and additional works at: https://pdxscholar.library.pdx.edu/soc_fac

Part of the Food Studies Commons, Politics and Social Change Commons, and the Rural Sociology Commons

Let us know how access to this document benefits you.

\section{Citation Details}

Daniel Jaffee and Philip H. Howard. 2010. "Corporate Cooptation of Organic and Fair Trade Standards." Agriculture and Human Values 27(4): 387-399. Doi: 10.1007/s10460-009-9231-8.

This Post-Print is brought to you for free and open access. It has been accepted for inclusion in Sociology Faculty Publications and Presentations by an authorized administrator of PDXScholar. Please contact us if we can make this document more accessible: pdxscholar@pdx.edu. 


\title{
CORPORATE COOPTATION OF ORGANIC AND FAIR TRADE STANDARDS
}

\author{
Daniel Jaffee ${ }^{1}$ and Philip H. Howard
}

This is the Accepted Manuscript (Author's Post-print) of an article published in the journal Agriculture and Human Values. Available online: https://doi.org/10.1007/s10460-009-9231-8

Citation: Daniel Jaffee and Philip H. Howard. 2010. "Corporate Cooptation of Organic and Fair Trade Standards." Agriculture and Human Values 27(4): 387-399. Doi: 10.1007/s10460-0099231-8.

\begin{abstract}
Recent years have seen a substantial increase in alternative agrifood initiatives that attempt to use the market to curtail the negative social and environmental effects of production and trade in a globalized food system. These alternatives pose a challenge to capital accumulation and the externalization of environmental costs by large agribusiness, trading and retail firms. Yet the success of these alternatives also makes them an inviting target for corporate participation. This article examines these dynamics through a case study of the two most significant such food system alternatives - organics and fair trade - focusing on corporate involvement in establishing and renegotiating the standards undergirding these initiatives. We compare the development of and contestation over the standards for both certified organic and certified fair trade, with particular attention to the U.S. context. We provide a brief history of their parallel processes of rapid growth and market mainstreaming. We examine claims of cooptation by movement participants, as well as the divergences and similarities between the organic and fair trade cases. Analyzing these two cases provides useful insights into the strategic approaches that corporate firms have deployed to further capital accumulation and to defuse threats to their profit margins and to status quo production, pricing, labor, trading and retailing practices. It can also offer valuable lessons regarding the most effective means of responding to such counter-reforms and of protecting or reasserting the more transformative elements at the heart of these alternative systems.
\end{abstract}

\footnotetext{
${ }^{1}$ Department of Sociology, Portland State University, Portland, OR, USA. Email: jaffee@pdx.edu
} 


\section{CORPORATE COOPTATION OF ORGANIC AND FAIR TRADE STANDARDS}

\section{Daniel Jaffee and Philip H. Howard}

\section{INTRODUCTION}

Within the space of a few weeks in late 2005 , two seemingly unrelated events occurred on opposite sides of the Atlantic that together symbolized a dramatic shift in the nature of alternative food systems. In late October, the Fairtrade Foundation in the United Kingdom granted the use of the fair trade seal to Nestlé, the world's largest food conglomerate and top coffee trader, for one small line of coffee on British grocery shelves (Tucker 2006:7). In early November, the U.S. Congress voted to approve the "Organic Trade Association Rider," a legislative clause heavily lobbied for by agribusiness interests, which overturned a federal court ruling and significantly weakened the four-year old USDA Organic standards (DuPuis and Gillon 2007). Despite major differences between the two decisions, both were indicative of the same dual phenomena: the increasing participation of corporate agrifood players in the profitable organic and fair trade "game," and their efforts to rewrite the rules of that game in ways that favor them. Both moves were highly controversial, unleashing vocal criticism from many consumers and activists that their respective standards had been "sold out" to corporate interests whose real intent was to render them toothless.

How does capital respond to social movements that attempt to use the market to curtail the negative social and environmental effects of production and trading in an increasingly globalized agrifood system? Many observers have analyzed the nature of the challenge posed by a multiplicity of "alternative" initiatives, originating in social movement activism, to the socially and ecologically destructive conventional capitalist relations that dominate the global food system. These alternative markets at least theoretically pose a challenge to companies' 
externalization of environmental costs and the exploitation of small farmers and waged laborers, thus constraining their commercial practices and potentially reducing their profits. As such, argue some observers, they represent a form of social regulation, a partial Polanyian "reembedding" of markets in systems of social and moral relations (Jaffee 2007; Mutersbaugh 2005; Raynolds 2000). Ironically, their success also makes them an inviting target for corporate participation, due to their creation of new spaces suitable for capital accumulation. The new corporate entrants have in many cases sought to weaken the threats posed by such alternatives, while simultaneously exploiting their potential for profits. In response, the founders of these alternative markets have worked to retain or restore their initiatives' original integrity.

This paper examines these issues through a case study of the two most significant such food system alternatives — organics and fair trade - focusing specifically on corporate involvement in the processes of negotiating, establishing, enforcing and reformulating the standards and certifications undergirding these initiatives.

There has been a great deal of attention in the rural sociological and agrifood systems literature to the increasing corporatization of these new market sectors, particularly organics (e.g., Guthman 2004a; Allen and Kovach 2000), and more generally to questions of market mainstreaming strategies and their attendant risks and benefits. Several observers have focused on the ways that corporate agribusiness, distribution and retailing firms have responded to the challenge posed by the standards and third-party certification undergirding organic and fair trade (e.g., DuPuis and Gillon 2007; Goodman and Goodman 2007; Mutersbaugh 2005; Jaffee 2007; Raynolds and Wilkinson 2007; Renard and Perezgrovas 2007). These strategies can be viewed as one part of what M. Fridell et al. (2008: 23) term a "corporate countermovement" against the regulatory impact of such agrifood schemes. Yet there has been little systematic examination of 
how large commercial interests have influenced the actual shaping of the organic and fair trade standards and rules themselves, and no exploration of the parallel manner in which this phenomenon has unfolded in both sectors.

In this paper, we compare the development of and contestation over the standards for both certified organic and certified fair trade, with particular attention to the U.S. context. We provide a brief history of their parallel processes of rapid growth and market mainstreaming. While corporate actors typically prefer to focus public and consumer attention on their "corporate social responsibility" and sustainability initiatives outside of the certification arenaand/or on first- or second-party certification schemes that require changes less substantive than those required by organic and fair trade - we argue that it is equally instructive to focus upon the direct or indirect corporate involvement in the (re-) formulation, (re-) definition, and (re-) shaping of the organic and fair trade standards and rules themselves. While organic and fair trade standards have followed different trajectories (e.g., the state nature of organic standards versus the civil society character of fair trade certification), we find that they are undergoing many parallel processes of cooptation. These include 1) at least partial regulatory capture of the institutions charged with applying the standards, and 2) the ongoing weakening or dilution of standards. Cross-cutting these phenomena is 3 ) a progressive sidelining of the deeper and more comprehensive social justice and/or sustainability critiques that had underlain the fair trade and organic alternatives from their inception.

We suggest that analyzing the differences and parallels between the fair trade and organic cases provides useful insights into the strategic approaches that corporate capital has deployed to defuse threats both to its profit margins and to its dominant production, pricing, labor, trading and retailing practices. It can also offer valuable lessons regarding the most effective means of 
resisting such counter-reforms and reasserting the more transformative elements at the heart of these alternative systems.

\section{COOPTATION, CAPTURE, AND THE WEAKENING OF STANDARDS}

How should one understand the choices made by the large commercial players who in many cases have opted to "join the game" in alternative agrifood markets - taking advantage of the profits offered by these niches and the integrity they represent to consumers-while at the same time attempting to neutralize the transformative power of the standards underpinning that integrity? Here we turn to conceptual frameworks from other arenas, including social movement literature focused on co-optation, and the public choice literature on the economics of regulation that examines regulatory capture.

Cooptation. The concept of cooptation has been developed most extensively in the sociological literature on U.S. social movements, beginning with Selznick's study of the Tennessee Valley Authority (1949), in which he describes cooptation as "the process of absorbing new elements into the leadership or policy-determining structure of an organization as a means of averting threats to its stability or existence," in either formal or informal ways. The term has since been used to describe the efforts of states or government entities to neutralize the effectiveness of movements for social change. Gamson $(1968 ; 1975)$ was instrumental in defining cooptation as an outcome in which a minority or movement group becomes institutionalized or is incorporated into the state, but without winning any substantive policy gains. More recently, cooptation has been used to describe the efforts of powerful political and economic actors, such as corporations, to maintain the status quo (Campbell 2001). While cooptation is a broad concept, we focus here on two specific processes: regulatory capture and attempts to weaken standards. 
Regulatory Capture. The concept of regulatory capture describes a situation in which parties with a strong interest in the outcome of regulatory decisions attempt to influence the bodies making such decisions, and in which those entities — charged with protecting the public interest — instead come to serve the commercial or special interests they are charged with regulating. Dal Bó (2006:203) defines regulatory capture broadly as "the process through which special interests affect state intervention in any of its forms." The concept originally emerged from public-choice economic theory. Stigler (1971) focused on the behavior of government agencies charged with regulation of monopolies, challenging the prevailing "public interest" view that regulators will mainly be motivated by a sense of duty to protect consumers from the abuses of monopoly power. In fact, regulatory experts often come to sympathize or directly identify with (and may indeed have come directly from) the industries they regulate. If the regulatory entity is staffed with people historically responsive to interests hostile to the market sector it is charged with supervising (e.g., the USDA in the case of organics), the probability of capture is even greater. Later work in this area has placed more attention on the role played by other interest groups (e.g., activists, consumers, environmentalists) in influencing regulatory agendas, on the organizational processes occurring within agencies themselves, and on the role of legislative bodies vis-à-vis regulators (Laffont \& Tirole 1991).

Weakening standards. One result of regulatory capture is increased power on the part of industry to weaken or dilute standards in ways that facilitate capital accumulation and deflect challenges to the status quo. Many observers of corporate involvement in organics and fair trade refer in some way to the "watering-down" of the integrity of standards, including (in organics) at the level of individual U.S. states and certifiers prior to passage of the federal organic law in 1990 (e.g., DuPuis and Gillon 2007: 4; Renard 2005: 420; M. Fridell et al. 2008: 30). One key 
effect of weakening standards is that it may lower the bar to entry, thus allowing the certification of actors and practices that would have previously been non-conforming, and bringing these alternatives closer to the status quo.

We now proceed to examine in greater detail the way these processes of movement cooptation, regulatory capture, and weakening of standards have played out in the organic and fair trade sectors. We note that this is an iterative process, in which instances of standards weakening are followed by social movement "push-back" that meets with varying degrees of success, leaving the door open to further efforts by conventional market players to redraw the boundaries of organics and fair trade.

\section{Standards Cooptation in Organics}

Organic food has undergone a well-documented transformation from a tiny movement to an industry worth more than $\$ 19$ billion a year in the United States (Anonymous 2008; Conner 2004; Fromartz 2006; Guthman 2004a; Pollan 2006). Bob Scowcroft, the former executive director of California Certified Organic Farmers and current executive director of the Organic Farming Research Foundation, described the motivations that led to its initial success: "Organic food emerged in the '70s as a product that reflected consumers' right to know how their food was grown and processed. Many different social, environmental, and farm-based objectives merged to promote organics as the only labeled alternative to an impersonal, chemically dependent, agroindustrial complex" (Scowcroft 2006: n.p.). As markets expanded beyond direct sales, certifying agencies were established to verify the claims that were being made. By the late 1990s, more than 40 certifiers were operating at the state or regional level, although standards varied slightly (Fetter and Caswell 2002; Hatamiya 1997). Increasing sales led to subtle pressures for these standards to conform to the requirements of markets, such as allowing any scale of farm to be 
certified organic (Guthman 2004a). As a result, some ideals were lost even before the national government became involved in regulating the organic sector.

In response to concerns about counterfeit organic products, some state governments began overseeing certification. In 1990, federal legislation-the Organic Foods Production Act of 1990 (OFPA) — was passed to create national organic standards with the rationale that it would eliminate the confusion of a patchwork of standards (OFPA 1990; Wolcott 2002). However, the OFPA was supported by powerful interests who stood to benefit from reducing the transaction costs of dealing with different certifying agencies when marketing nationally. The legislation authorized oversight by the U.S. Department of Agriculture, an agency that traditionally has been hostile to alternative farming practices, including organic (Vos 2000). The first draft of the national standards was finally released in December 1997, and included provisions that would allow the "Big Three" agricultural practices in certified organic food: 1) irradiation, 2) sewage sludge and 3) genetically engineered organisms.

The organic movement helped mobilize an enormous public response to this proposal, with the USDA receiving 275,603 comments, the vast majority opposed to the inclusion of the Big Three in the definition of organic (Fromartz 2006; Shulman 2003). While the number of people commenting was unexpected, the comments themselves were not, as the proposal to include practices far from the organic ideals was very effective in focusing attention on allowable inputs, to the exclusion of other goals (Goodman and Goodman 2007). Organic food processor Eden Foods, suggesting that this was a deliberate strategy, said, "we recognized the 'Big Three' as a common negotiating tactic: Make an offer that is so ridiculously unacceptable that all future offers would seem good by comparison" (Eden Foods 2006: n.p.). In October, 2002, nearly five years after the first draft of the organic rule was released, a third draft went into effect as the final 
rule. It excluded the Big Three and was fairly strict with respect to prohibiting other unacceptable inputs (such as antibiotics and synthetic fertilizers and pesticides), but also removed references to the higher ideals of organic found in some regional certification systems. Importantly, the national standard creates a "ceiling" by prohibiting organic certifiers from enforcing stricter standards than those required by the USDA, even those they previously maintained. As a result, the activist group Organic Consumers Association (OCA) derisively refers to the USDA organic label as "Grade B Organic" (Cummins 2002).

Throughout this process of centralizing state authority over the meaning of organic, sales of certified organic foods in the US have increased dramatically, with an average 20 percent annual growth almost every year since 1990 (OTA 2007). The availability of organics has also expanded to the point that nearly half of sales are now through mass market channels such as supermarkets and warehouse clubs (OTA 2006). Organic products can even be found in an increasing number of fast food restaurants and vending machines, and nearly three quarters of consumers surveyed report purchasing organic foods at least occasionally (Kavilanz 2008).

Among the consequences of this rapid sales growth and the accompanying development of national certification systems have been rapid industry consolidation and increasingly capitalist behavior in the off-farm segments of the organic food system (Allen and Kovach 2000; DeLind 2000; Ikerd 1999). The extent to which this has occurred is demonstrated by the fact that 14 of the 20 largest food processors in North America have either acquired organic brands or introduced organic versions of their existing brands (Howard 2008). There is also evidence that organic farms are increasing in scale and using more capital intensive inputs and production 
Table 1 Cooptation in organic

\begin{tabular}{|c|c|c|}
\hline A: Process & B: Domain & C: Specific instances or claims \\
\hline \multirow[t]{5}{*}{ Regulatory capture } & Reduced democratic input & $\begin{array}{l}\text { Increasing industry representation on NOSB, even in designated 'public/ } \\
\text { consumer' and 'environmentalist' seats (Cummins and Eidinger 2006). }\end{array}$ \\
\hline & & $\begin{array}{l}\text { USDA bypassed NOSB authority for: (1) } 1997 \text { proposal to allow the "Big } \\
\text { 3"-irradiation, genetic engineering, sewage sludge; (2) three guidances } \\
\text { and a directive in } 2004 \text { to allow controversial inputs and extension to non- } \\
\text { food products (Ness 2004). }\end{array}$ \\
\hline & Limited regulatory oversight & $\begin{array}{l}\text { Limited oversight of certifiers, such as no site visits in China until } 2007 \\
\text { (Lavigne 2006). }\end{array}$ \\
\hline & & $\begin{array}{l}\text { USDA deal to allow Aurora Dairy to correct } 14 \text { willful violations of pasture } \\
\text { requirements without penalty in } 2007 \text { (McKinney 2007). }\end{array}$ \\
\hline & & No prosecutions of violators to date (Lavigne 2006). \\
\hline \multirow[t]{7}{*}{ Weakening standards } & Definition of access to pasture & $\begin{array}{l}\text { Increasing number of feedlot-scale dairies, such as those operated by Aurora } \\
\text { and Horizon (Fantle 2008). }\end{array}$ \\
\hline & & $\begin{array}{l}\text { USDA overturned Massachusetts certifier's decision to revoke certification of } \\
\text { Country Hen for inadequate outdoor access in } 2002 \text { (Fiser 2007). }\end{array}$ \\
\hline & Definition of allowable inputs & $\begin{array}{l}\text { Congressional rider to an appropriations bill to allow feeding conventional } \\
\text { feed to 'organic' chickens passed in } 2003 \text { (though eventually overturned } \\
\text { due to public pressure) (Food and Drink Weekly 2003). }\end{array}$ \\
\hline & & $\begin{array}{l}\text { Organic Trade Association sponsored Congressional rider, which included } \\
\text { allowing synthetic ingredients in processed organic foods, to an } \\
\text { appropriations bill passed in } 2005 \text { (DuPuis and Gillon 2009). }\end{array}$ \\
\hline & & $\begin{array}{l}\text { USDA allowance of non-organic 'minor ingredients' in processed foods in } \\
2007 \text { (Wilson 2007). }\end{array}$ \\
\hline & Extension to other products & $\begin{array}{l}\text { USDA directive stated intention of non-interference with organic claims for } \\
\text { fish, pet food or body care products in } 2004 \text { (although settlement reached } \\
\text { with Organic Consumers Association and Dr. Bronner's to take more } \\
\text { enforcement actions in 2005) (Myers 2008). }\end{array}$ \\
\hline & & $\begin{array}{l}\text { Definition of organic fish-farmed and raised with non-organic feed- } \\
\text { proposed in } 2008 \text { (Eilperin and Black 2008). }\end{array}$ \\
\hline
\end{tabular}

techniques, although the wide applicability of the "conventionalization thesis" to areas outside

California is debated (Buck et al. 1997; Guthman 2004b; Lockie et al. 2006).

\section{Capturing Organic}

From the perspective of the original organic movement, there have been repeated attempts

by the USDA and/or by increasingly capitalistic actors within the industry to capture the

governance structure of the national organic standards, primarily with respect to reducing

democratic input into the standards setting process and limiting regulatory oversight of certifiers. 
Reducing democratic input. Some measure of representative participation in the regulation of organic foods was enshrined in the original OFPA legislation through the creation of the National Organic Standards Board (NOSB). The NOSB advised the USDA on the development of the standards, and is currently involved in matters such as determining allowed and prohibited substances. However, the composition and authority of this board is an ongoing area of contention. While the 15-member board has representatives designated for certain categories (four organic producers, two organic handlers, one retailer, three environmentalists, three public/consumer representatives, one scientist, and one certifying agent), ultimately these appointments are made by the Secretary of Agriculture (USDA 2008), and many critics charge that they are politicized. Merrill Clark, a founding member of the NOSB (1992-1996), reflected on the non-movement orientations of many of her board peers: "I ended up being the chair of the livestock committee and a member of the processing committee. I knew something was wrong when the chair of that processing committee (from Checkerboard Square/Purina, making Earth's Best organic baby food) asked, 'How many of you think it's OK to add some synthetics to 90100 percent organic foods?' And all the hands went up...but mine! What meeting was this?" (Clark 2007: n.p.).

Beyond the issue of the politicization of the NOSB, in many instances the USDA and other actors have simply bypassed the Board entirely. While Clark had her disagreements with other members, the NOSB as a group took the position that USDA officials did not have the authority to add new items to their list of allowed substances. The USDA, however, in an internal memo justified the inclusion of the "Big Three" practices on the basis of a typographic error: they 
pointed out that in the 1990 OFPA legislation, the phrase "National List" was not capitalized in one instance (Hatamiya 1997). The co-authors of the law, Rep. Peter DeFazio (D-OR) and Sen. Patrick Leahy (D-VT), said this was clearly not their intent, with DeFazio stating that the USDA risked a legal challenge with this creative interpretation (Broydo 1998). A similar disregard for the rules occurred in 2004, when USDA staff issued changes in three "guidances" and one "directive" that would have weakened organic standards, without NOSB input or a public comment period (Ness 2004), as we discuss further below.

Although the USDA was forced to withdraw those particular revisions, important changes in the makeup of the NOSB were soon to follow, due to the expiration of some members' terms. In 2005, Daniel Giacomini, a consultant to the dairy industry, and Katrina Heinze, a manager at General Mills, were appointed as the "public/consumer" representatives to the Board. Due to criticism from groups including the OCA and Consumers Union, Heinze stepped down (Organic Business News 2006), but she currently serves on the NOSB as a "scientist" representative. Other current members who are seen to be more representative of industry than their designated position dictates include Tracy Miedema of Stahlbush Island Farms as a "public/consumer" representative, and Tina Ellor of Phillips Mushroom Farms as an "environmentalist" representative (neither of their businesses are 100 percent organic) (Cummins and Eidinger 2006).

Limiting regulatory oversight. The outgoing NOSB chair, Jim Riddle, has publicly criticized the USDA for inadequate oversight in its accreditation of certifying agencies, the organizations it authorizes to carry out inspections of operations. As organic commodity chains 
have become global, more than 40 percent of these agencies are now based outside of the U.S. China has almost four times as many certified organic acres as the U.S. (8.6 million acres), with 90 percent of that land certified in 2004 alone. However, there had been no site visits to China by the USDA until late 2007, and Riddle expressed skepticism that the required three-year transition period could have been properly implemented in such a short time (Lavigne 2006). Giving weight to his doubts were reports that Wal-Mart had removed "organic" produce from one of its stores in China after a surprise inspection of the farm near Beijing uncovered pesticide applications (Tschang 2007). The issue of auditing and enforcement within the U.S. is also a contentious one. Riddle pointed out in 2007 that "there have been no prosecutions of the violations for the organic law yet...They've failed to take action" (Lavigne 2006: n.p.). Some certifiers, such as Quality Assurance International, have been criticized within the organic industry for their lax approach to inspections, and some critics snidely refer to QAI as standing for "Quick And Immediate" (Guthman 2004a; Alpert 2007). In contrast, when Massachusetts Independent Certification, Inc. rejected the application of the egg producer The Country Hen in October, 2002 because the producer did not provide its chickens adequate access to the outdoors, the certifier was overruled by the USDA.

\section{Attempts to Weaken Organic}

Corporations and/or corporate-aligned actors involved in the regulation of organic have attempted to weaken standards in three main areas, 1) the definition of access to the outdoors and pasture for animals, 2) the definition of allowable inputs, and 3) the extension of organic labels to fish, pet food and non-food products. In each of these areas there have been multiple 
instances of politicized, arbitrary, or weak enforcement of the standards, the rewriting or bending of rules, backroom deals with industry, the overruling of certifiers by USDA officials, and even direct interference by Congressional representatives, with the explicit goal of benefiting specific industries and/or particular companies.

Access to the outdoors/pasture. The issue of access to the outdoors for animals, which is defined only vaguely in the current standards, has remained one of the most visible controversies. Much of this has been due to the work of the non-profit Cornucopia Institute, which since 2004 has campaigned against large feedlot 'organic' dairy operations. In 2007, USDA certification was suspended for a 10,000 cow operation in California owned by Case Vander Eyk, Jr., who was selling a portion of the milk as organic. However, this action was kept secret by the USDA and other involved parties, until the Cornucopia Institute learned of it through a whistleblower (Fantle 2008). Similar violations by Aurora, a supplier of private label organic milk from operations including feedlots with over 4,000 cows, resulted in a USDA threat to revoke their certification that same year. However, a secret deal to correct the 14 "willful" violations was reached between Aurora and the USDA over a period of 18 months, with no fines or suspensions of certification for the firm or its certifiers (McKinney 2007). This agreement was also exposed through an insider tip and a Freedom of Information Act request by the Cornucopia Institute (Cornucopia Institute 2007). The revelations then led to class-action lawsuits against Aurora and its retail customers for falsely selling "organic" milk (Johnson 2007). Despite surveys that indicate the majority of organic consumers do not support confinement agriculture (Margulis 2006), the National Institute for Animal Agriculture (a trade association) is pushing to 
change organic standards to actually prevent access to the outdoors, claiming this action is necessary to protect poultry from contracting bird flu (NIAA 2007).

Inputs. Poultry was also the locus for another controversy involving a change in allowed and prohibited organic inputs, and is an example of the most direct form of political interference in the standards to benefit specific corporations. At the behest of chicken producer Fieldale Farms, Rep. Nathan Deal (R-GA) attached a rider to an appropriations bill in 2003 that would allow the use of conventional feed for livestock if the price of organic feed was two times higher than conventional, and still be certified "organic." Although this move was temporarily successful, more than 300,000 consumer complaints to members of Congress quickly triggered legislation to repeal it ${ }^{2}$. The Organic Trade Association (OTA) was one of the most vocal critics of this "stealth" rider, including taking out a full page advertisement in the New York Times (Food and Drink Weekly 2003). Ironically, the OTA itself went on to use the same strategy to legalize synthetics in processed organic foods (among other changes) in 2005, as noted above ${ }^{3}$. The previous year, the USDA issued a directive that would have sanctioned the use of antibiotics in organic dairy cattle up to 12 months before producing "organic" milk, and a guidance that would have allowed toxic synthetic pesticides if they were so-called "inert" ingredients not required to be listed on the label. These changes were rescinded, but the agency came under

\footnotetext{
${ }^{2}$ Fieldale Farms had made previous efforts to use conventional feed for "organic" chicken, including even setting up their own certification agency for a time, and then attempting to negotiate a "back room deal" with the USDA to change the rules. The deal was blocked under pressure from organizations including the OTA and the National Campaign for Sustainable Agriculture (Nesmith 2002).

${ }^{3}$ DuPuis and Gillon (2007) discuss the successful lawsuit by Arthur Harvey, a Maine blueberry farmer, who successfully challenged the USDA's interpretation of the use of synthetics in the 1990 legislation, as well as the OTA's response, which overturned Harvey's victory.
} 
further criticism in 2007 when it clarified that only 38 non-organic, agricultural "minor ingredients" were allowed in certified organic products. This list included hops, at the request of beer giant Anheuser-Busch, along with fish oil and intestines for sausage casings (Wilson 2007b). Only a seven-day public comment period was originally allowed for this change, but the USDA still received over 1,000 signatures in opposition, and subsequent USDA inaction led Anheuser-Busch to pledge to source organic hops (Wilson 2007a).

There has even been discussion of returning two of the "Big Three" as allowable inputs. If irradiation were "proven effective at eradicating pathogens while preserving the freshness and nutritional integrity of the food without causing adverse environmental effects, then the National Organic Standards Board might reconsider those rules," said Will Daniels, a vice president of Earthbound Farm, the organic processor implicated in a 2006 outbreak of E. coli bacteria (Cone 2008). Other interests are lobbying for the renewed inclusion of genetic engineering. University of California-Davis plant pathologist Pamela Ronald and her husband Raoul Adamchak, an organic farmer, are among those advocating removal of the prohibition of genetically engineered organisms in organic agriculture (Ronald 2008). The Biotechnology Industry Association is pushing for at least a global uniform standard of "acceptable" levels of GMO contamination (Weiss 2004).

Extension to other products. Another directive issued and quickly rescinded in 2004 stated that the USDA would not intervene if fish, pet food, or body care products make organic claims. Many companies in these industries had made investments to meet USDA organic standards, and were upset to be put at competitive disadvantage. The OCA and Dr. Bronner's (a soap company) 
filed a joint lawsuit in 2005 to prevent USDA inaction. They agreed to a temporary settlement that does not allow the USDA Organic seal to be displayed on pet food or body care products unless it meets the food standards (Myers 2008). However, fish is an ongoing area of controversy and the NOSB is still considering how to implement organic standards in this arena (Mansfield 2004; Sung 2008).

Perhaps the most notable element of the preceding narrative is the large number of instances in which the USDA, Congress, or even the NOSB have made questionable, surreptitious, or extra-legal changes to the standards, many of which were later rescinded or curtailed after publicity, pressure, or lawsuits from citizens or advocacy groups. This dynamic illustrates how the effort to capture the standard-setting process and to weaken organic standards generates an iterative process. Due to resistance from social movement actors, efforts at cooptation have achieved varying degrees of success.

\section{Cooptation of Fair Trade Standards}

The development of the international fair trade system is, on one hand, a success story of the use of standards and certification to "scale up" an alternative market, reaching increasing numbers of consumers through mainstream retail venues, and partially redressing the unjust terms of commodity trade by redistributing capital through guaranteed minimum prices. However, it can also be read as a different sort of tale: one of partial capture of the alternative by large commercial participants who have engaged with it at only token levels, the weakening of standards by those market forces, the distancing of key governance bodies from the producers 
they ostensibly serve, and the dilution of the movement's transformative power and its relational character.

At its inception, the fair trade movement was centered on a fundamental critique of the structural injustice of global trade. It was framed as an effort to redress the disadvantageous social and economic conditions faced by small commodity producers in the global South by linking them more directly with "conscious consumers" in the North, thus bypassing most conventional intermediaries. With its twin roots in development charities and radical solidarity NGOs in Europe and the U.S., the movement was initially characterized entirely by the Alternative Trade Organization (ATO) model, in which goods from producer cooperatives are sold through non-profit organizations or ethical for-profit businesses (Raynolds and Wilkinson 2007: 36).

The formation of the first fair trade certification - the Max Havelaar seal in the Netherlands in 1988 - was the culmination of efforts to reach a substantial consumer base for the products of small farmer cooperatives, yet it also began the movement's ongoing struggle with the practical and ethical dilemmas involved in market mainstreaming. Use of the seal was initially informal and was regulated by the civil society initiatives themselves. Eventually, these entities began to formalize certification criteria and practices, and in 1997 the 17 European fair trade national initiatives (or NIs) came together to form an international umbrella certifier, Fairtrade Labelling Organizations International (FLO), which assumed the responsibilities for establishing uniform international fair trade standards, approving new products, and setting minimum prices. Formal certification did not arrive in the U.S. until 1999, with the creation of the national certifier Transfair USA. Almost immediately, the young movement began to encounter the tensions associated with growth. How was it to make fairly-traded goods available to mass consumer 
audiences while still remaining true to the core values of the initiative, which emphasized creating direct, long-term trading relationships?

Fair trade has also undergone a marked process of institutionalization, as the national and international certification bodies became formalized and pressures for rigorous third-party certification and standards grew. As additional NI's were established in newer fair trade consumer countries, the social movement character was not always firmly implanted in their institutional "DNA." In particular, Transfair USA, based in Oakland, California, has from its inception been marked predominantly by a business-oriented model, with civil society ties playing a negligible role in its governance structure. By the end of the 1990s, the NIs had largely standardized their functions and ceded a good measure of discretion and authority to FLO, based in Bonn, Germany. ${ }^{4}$ FLO itself became more professionalized, and has been the site of contestation between competing interests in the growing fair trade market (Renard 2005: 425).

The corporatization of fair trade began, perhaps ironically, with an activist campaign targeting the multi-billion-dollar specialty coffee giant Starbucks, which had faced substantial criticism for its labor and pricing practices. A number of NGOs, led by San Francisco-based Global Exchange, insisted that Starbucks begin to purchase and offer fair trade certified coffee. In April 2000, just before the activists were set to launch simultaneous protests in 29 cities, the company relented and promised to sell fair trade coffee in all of its U.S. stores. In the years since this development, a wide range of new commercial actors have entered the fair trade system. Other large specialty coffee roasters (e.g., Green Mountain Coffee Roasters) sought certification in order to compete with Starbucks. Some corporate mass-market roasters (e.g., Procter \& Gamble and Nestlé) also have also followed suit, as have large restaurant chains (e.g. Dunkin Donuts and McDonalds) and retail chains with fair trade goods in store brands (e.g. Costco and

\footnotetext{
${ }^{4}$ Today there are 20 NI's recognized by FLO, with others in the process of applying for recognition.
} 
Wal-Mart). This strategy has been effective at boosting consumer demand; annual growth of the global fair trade market has averaged over 40 percent (FLO 2007).

\section{Attempts to Weaken Fair Trade}

In their discussion of the rise of non-state regulation, Raynolds et al. distinguish between standards that "raise the bar," leading to improvements in social and environmental conditions, and those that "hold the bar," merely preventing further degradation $(2007: 148,150)$. While they include fair trade standards in the former group, the current context of fair trade can be described as one in which there is considerable pressure from the new corporate participants to once again lower the (raised) bar.

There has been a vigorous ongoing debate within the fair trade movement regarding the benefits and drawbacks of the system's mainstreaming or corporatization. But what some participants may not have been anticipated at the outset was how the dominant food corporations would use their market power to push for changes in the rules of the game, in order to reduce or eliminate the threat posed by the standards to their existing pricing, labor and commercial practices. These pressures have played out in three key areas: 1) entry requirements, 2) the level of fair trade minimum prices, and 3) certification of plantation agriculture.

Entry Requirements. The first instance of cooptation in the U.S. fair trade setting was the decision to lower the bar for entry into the certification system. Until 2000, there had been an agreement that in order for a company to place the fair trade seal on any of its products, at least

five percent of its total purchases had to be made at fair trade terms from cooperatives on the international fair trade register (Jaffee 2007: 203-204). This informal policy was intended to prevent appropriation of the seal by low-road competitors. However, the agreement was breached when Transfair USA brought Starbucks to the negotiating table; the coffee giant 
entered the FLO/Transfair system with approximately one percent of its purchases at fair trade terms. $^{5}$ Since 2000, other coffee transnationals (e.g., Procter \& Gamble and Nestlé) have struck deals in the U.S. and UK to enter the system while purchasing less than one percent fair trade. To the movement pioneers, however, this move was antithetical to the integrity of the standards. Rink Dickinson, the co-director of Equal Exchange, said that "to get the multinationals to play in the fair trade game, certifiers such as Transfair have basically cut a deal with the multinationals, on pretty bad terms. [They say] 'Well, we really want you guys in the game, which is really important. And we're basically willing to give you most of the things that you want, to play this game"" (Personal communication, 2005).

Transfair USA no longer stipulates any particular purchase level to qualify for use of the seal, nor is there any requirement for specific increases over time; these details are negotiated in private deals with individual firms. The certifier's website makes its position on the issue clear: "[p]articularly for large companies, it is unrealistic to expect them to convert large portions of their overall business to Fair Trade overnight, before demand has been proven .... If we take a rigid approach with regard to minimum volumes or percentages — presumably in defense of the credibility of the label—we could potentially lose significant volume to the detriment of the farmers we seek to serve" (Transfair USA 2007). Yet without a requirement for firm minimum (and rising) purchasing levels, fair trade risks becoming a tool for corporations to engage in "fair-washing," reaping substantial public relations benefits while engaging with fair trade at merely token levels. These firms clearly see fair trade as a profitable niche and a useful corporate social responsibility tactic, but critics argue the certifiers have a responsibility to force

\footnotetext{
${ }^{5}$ As of this writing, Starbucks claims to purchase six percent of its coffee from fair trade sources (Starbucks 2008); however, some of that amount may be resold to other roasters.
} 
corporations to go beyond this niche, instead using fair trade as mechanism to leverage corporate accountability (Reed 2008).

In 2004, after working both publicly and behind the scenes to address their complaints with the policies of Transfair USA, five small, 100-percent fair trade coffee roasters (all members of the Cooperative Coffees network) left the FLO/Transfair certification system entirely. One of the defectors, Matt Earley, co-owner of the roaster Just Coffee, told the Christian Science Monitor that "without people outside the increasingly corporate-friendly Transfair system pushing for the original vision of a better model, [the movement] will be watered down into nothingness" (Rogers 2004). The five companies have continued to purchase coffee from fair trade cooperatives and label it as "fairly traded," but no longer use the Transfair label or pay licensing fees, instead giving the money directly to the producer groups in the form of a higher price. These and other movement-oriented fair trade companies, along with NGO and activist allies, have also succeeded in sparking a debate within the movement over the costs of corporatization and cooptation, juxtaposing "Fair Trade Lite" against the notion of "Deep Fair Trade," and disseminating lists of 100 percent fair trade businesses (e.g., Global Exchange 2007).

Minimum Prices. The base prices for fair trade products (at first only coffee) were initially established by movement NGOs in the 1980 s, based on international studies of production costs and producer livelihoods. The setting of prices became the purview of FLO after its creation in 1997. Prices are thus an integral part of FLO standards, one of the most important. A "fair price" was the raison d'etre for fair trade's creation, and it is arguably upon the premise of a fairer price that the moral power of the system continues to rest. 
Table 2 Cooptation in fair trade

\begin{tabular}{|c|c|c|}
\hline A: Process & B: Domain & C: Specific instances or claims \\
\hline \multirow[t]{3}{*}{ Regulatory capture } & Reduced democratic input & $\begin{array}{l}\text { Professionalization of FLO leads to ISO certification (2007), aligning fair } \\
\text { trade with trend toward global harmonization of agrifood standards and } \\
\text { away from small farmer concerns (Mutersbaugh 2005; Fair Trade } \\
\text { Association of Australia and New Zealand 2007). }\end{array}$ \\
\hline & & $\begin{array}{l}\text { Southern producer groups remain a clear minority on FLO board of directors } \\
\text { and key committees, despite recent increase in representation (Renard and } \\
\text { Perezgrovas 2007; FLO 2007b; FLO 2008a). }\end{array}$ \\
\hline & Limited regulatory oversight & $\begin{array}{l}\text { Licensing fee structure leads to lack of independence, creates disincentive to } \\
\text { carefully regulate high-volume licensees (Bahra 2009). }\end{array}$ \\
\hline \multirow[t]{7}{*}{ Weakening standards } & Lowered entry requirements & $\begin{array}{l}\text { Fair Trade seal granted by Transfair USA to Starbucks in } 2000 \text { for only } 1 \% \\
\text { of coffee purchases, altering agreement not to certify below } 5 \% \text { of total } \\
\text { sales. Significant opposition from movement NGOs and smaller roasters } \\
\text { (Rice } 2005 \text {, personal communication; Bahra 2009). }\end{array}$ \\
\hline & & $\begin{array}{l}\text { Nestle granted fair trade seal (UK) in } 2005 \text { by Fairtrade Foundation, over } \\
\text { objections of many fair trade organizations. Nestlé's Partners Blend } \\
\text { represents a fraction of } 1 \% \text { of Nestlé coffee purchases (Crowther 2005; } \\
\text { Tucker 2006). }\end{array}$ \\
\hline & Fair trade minimum prices & $\begin{array}{l}\text { Falling real value of minimum prices; Coffee price not adjusted for inflation } \\
\text { until minor } 2007 / 2008 \text { increase; has still lost } 30-60 \% \text { of original (1988) } \\
\text { purchasing power. Farmgate fair trade prices remain below cost of } \\
\text { production for many producers (Bacon and CLAC 2006; Jaffee } 2007 \text { ). }\end{array}$ \\
\hline & & $\begin{array}{l}\text { Proposals within FLO to lower or eliminate minimum prices for coffee; } \\
\text { social premium for tea lowered in } 2008 \text { (Bastian 2006; FLO 2008c). }\end{array}$ \\
\hline & Certification of plantation agriculture & $\begin{array}{l}\text { FLO dramatically increased certification of agribusiness plantations since } \\
2003 \text { for all but four products (coffee, cotton, cocoa and honey); many new } \\
\text { products (e.g., cut flowers) introduced with exclusively and/or } \\
\text { predominantly plantation production (Goigoi 2008). }\end{array}$ \\
\hline & & $\begin{array}{l}\text { FLO wage-labor standards for plantations do not guarantee union } \\
\text { representation (only right to unionize); fair trade social premiums are } \\
\text { jointly administered by management and workers through controversial } \\
\text { joint associations. Standards only require payment of national minimum } \\
\text { wage, not living wages (FLO 2008b; Goigoi 2008; Bahra 2009). }\end{array}$ \\
\hline & & $\begin{array}{l}\text { FLO and national initiatives court large transnational firms for licensing deals } \\
\text { (e.g., Chiquita), and fail to protect small producers from unfair price } \\
\text { competition from certified plantations (Tucker 2006). }\end{array}$ \\
\hline
\end{tabular}

However, these prices must be understood as political, in the same way as the list of

allowable materials in organic production is a political artifact. Fair trade's impact rests in large

part upon its redistributive potential — the extent to which it shifts capital from retailers and

distributors "upstream" along the commodity chain to cooperatives, producers, and in some cases

waged laborers. ${ }^{6}$ While that redistribution is achieved through fair trade's minimum prices,

those prices are a site of ongoing contestation. Since the movement's inception the minimum

${ }^{6}$ Of course, it is not merely the existence of price premiums per se, but the level of prices multiplied by actual sales volumes, that determines the extent of the redistributive impact. 
price levels have come to reflect not a calculation of what small farmers need to sustain family livelihoods, but rather the prevailing balance of power between different groups of participants in the coalition: producers, certifiers, distributors, and retailers both small and large.

Thus, while inflation in producer countries has soared in the 20 years since the movement's inception, the minimum prices for coffee have remained virtually stagnant. A study by Bacon et al. (2006) documents that real fair trade coffee prices (adjusted for inflation) fell by 39 percent between 1988 and $2005 .^{7}$ This deterioration is further compounded by new fees charged by FLO to producer groups for certification, and the high costs of organic certification. There have even been proposals within FLO to lower the base price or eliminate it altogether; these reflect the demands of the large traders who have entered the initiative to keep their costs low (Renard and Perezgrovas 2007: 149). Bastian (2005) quotes Guillermo Denaux, the FLO regional coordinator for Central America: "Even though there is a lot of pressure to change [the minimum price]...since it is so difficult to find common ground between buyers and sellers, there has been little movement." The minimum prices are important because they represent the sole way in which fair trade redresses the unjust distribution of returns along the commodity chain. To the extent that minimum prices do not keep pace with increases in producer costs, the initiative is actually shifting capital further away from producers toward the retail end of the chain.

After substantial mobilization by producer groups, FLO agreed to a minor increase in the coffee base prices in 2007 ; they were raised by a nickel to $\$ 1.31$ per pound for conventional coffee and by a dime to $\$ 1.51$ for certified organic. However, as of this writing, the minimum price would need to be well above $\$ 2.00$ per pound to regain its original purchasing power (Bacon et al. 2006).

\footnotetext{
${ }^{7}$ This calculation used only the U.S. Consumer Price Index; the loss of purchasing power in producer countries has been much greater.
} 
Certification of Plantations. The cooptation of fair trade standards is notably similar to that of organics in the way it has opened the door to conventionalization; this dynamic is most visible in the certification of agribusiness plantations in fair trade. Fair trade—like organic —was originally intended as a system involving small farmers; in the global South, this meant marginalized peasant producers of tropical export commodities. As fair trade expanded beyond coffee, certifiers occasionally turned to small, progressive estates or plantations to fill the gap. They created a second "modality" in fair trade for waged workers, in which certification is based on allowing workers the right to unionize, payment of national minimum wages, and the payment of price premiums into an independent fund for the benefit of workers, to be managed by an organization jointly run by workers and owners. More recently the number of certified plantations has skyrocketed, as FLO has attempted to meet retailers' demands for a greater variety of fair trade products, such as fresh produce sold under "own brand" labels at major retail chains (Barrientos et al. 2007). This "fast track" growth strategy has caused major rifts within the movement. In seeking a source of bananas for the U.S. market, for example, Transfair USA overtly sidelined social movement participants in order to negotiate directly with number-two banana giant Chiquita (and international banana union COLSIBA) to certify a corporately-owned plantation in Honduras, a deal that was ultimately unsuccessful (Raynolds 2007).

Organizations of small producers have strongly opposed the extension of fair trade certification to plantations. One of the concerns they voice is that their cooperatives will be undercut by the high volumes and economies of scale involved in plantation production, and thus lose their markets. Carmen Iezzi, director of the Fair Trade Federation, charges that "the large companies want to continue working with mass producers like plantations rather than going the tougher route, which is identifying small farmers and buying from them" (quoted in Goigoi 
2008). Other critics add concerns that the benefits to workers are nebulous: national minimum wages are a notoriously inadequate benchmark, the "independent" worker-management organizations have an uneven track record at best; and there is no requirement of unionization (only the right to unionize), leaving the door open for labor rights violations. Indeed, in Colombia — a nation notoriously dangerous for unionists — not one of the fair trade certified cut flower plantations is unionized (Goigoi 2008). This small producer opposition has met with some limited success: there has been an agreement to keep four commodities free of plantation certification for the present: coffee, cocoa, honey, and cotton (Renard 2006: 7). Beyond these products, however, FLO continues to rapidly expand the plantation sector, shifting the profile of fair trade steadily toward large-scale conventional agriculture.

\section{Capturing Fair Trade}

Who makes the key decisions affecting the governance of fair trade, and whose interests are represented? Just as the NOSB — initially intended to provide a counterweight to industrial agriculture interests in the governance of organics — experienced partial capture by those same interests, so has the global certifier FLO been the locus of struggles over the relative power of movement and market forces, and of Northern versus Southern interests. It is important to distinguish between the realms of formal power (votes) and informal power, whether economic, political, or ideological. For several years there was little or no representation by Southern fair trade producers on the FLO board of directors and committees, which establish the rules and prices that directly affect their livelihoods. While the producer organizations - after years of political organizing - have won more substantial formal representation in FLO's governance structure (albeit still a minority), the changes at the levels of informal power and institutional culture may have more profound effects, as the shift toward plantation certification attests 
(Renard and Perezgrovas 2007: 149). As FLO has professionalized, the conceptual and cultural distance has grown between the administrators and the producers they ostensibly represent (Renard 2006). Moreover, the shift toward mainstream markets, plantation agriculture and corporate participation has changed the institutional culture and the informal center of power within FLO. The large firms now make a more substantial financial contribution to FLO and some NIs (through license fees) than before; the resistance of those players to increased costs likely played a role in FLO's long-standing refusal to raise fair trade minimum prices, as discussed above. Cementing the trend toward professionalization, FLO in 2004 formally split into two separate entities: FLO-Cert, which handles all certification activities involving producers and importers, and FLO International, the main body setting standards, prices, and policies for fair trade globally. This division was made in order to align the organization for ISO 65 certification (Raynolds et al. 2007: 19-20; Renard 2005: 425), which FLO-Cert eventually achieved in October 2007. The ISO framework and related global standards, however, are not a neutral phenomenon; Mutersbaugh argues that the "organic and fair-trade certification standards are being progressively removed from their network crucibles and institutionally (re)embedded" in multilateral entities such as the WTO (2005: 2037-2039). Despite positive changes in the realm of formal representation, then, the agenda of fair trade - envisioned as a way to leverage economic justice for small Southern producers — continues to be set mainly by Northern players, both commercial and non-governmental.

\section{DISCUSSION}

Before analyzing the lessons to be drawn from the processes that have played out in both organic and fair trade standards, it is worth reviewing the areas where these two cases overlap, and where the differences are more pronounced. 
The similarities between the standards-related changes in these two arenas, as we indicate above, are numerous. First, organics and fair trade share similar social movement origins, emerging out of different facets of the political and ecological critiques of the countercultural movements of the 1960's; both also depended for their initial growth on the consumer cooperative movement initiated during this period. Second, for both organics and fair trade, the market (rather than the state) is the primary target of the initiative: they seek to harness market forces to changes the ecologically and social destructive tendencies of the dominant or mainstream capitalist markets in agriculture — in the words of Barratt Brown (1993: 156), they work "in and against the market"- and both movements have experienced deep tensions between their foundational ideals and the constraints of that market system. Both initiatives have encountered enormous pressure to alter their standards to allow for an increased scale of production, augment sales, meet consumer demand, and fit better with the production patterns of conventional agribusiness. This has generated a clear conflict with the ideals of smallholder agriculture that guided the creation of both initiatives. Both movements have also experienced pressure to work with large publicly-traded or transnational firms and large mainstream growers, causing a clash between the profit motives of those "disembedded" players and the core movement values that proclaim the value of social and environmental integrity over prices and the bottom line.

Third, in both cases there has been a movement subsidy to the market, as corporate actors reap profits from exploiting the niches that were painstakingly built by grassroots activist movements, appropriating or coopting both the discourse and the actual product seals generated by that activist labor (Barrientos et al. 2007). Fourth, there has been an uneven penetration of capitalism within both sectors, with some branches of each retaining greater autonomy and/or 
integrity than others (e.g., the four non-plantation commodities in fair trade, and certain high value, difficult-to-mechanize crops within organics). Fifth, the governance of both initiatives has undergone "institutional isomorphism" (DiMaggio and Powell 1983; Ransom 2007): the increasingly corporate-friendly stance of FLO, Transfair USA, and the NOSB has led not only to a shift in institutional culture, but also greater "professionalization," in which these bodies increasingly come to resemble the companies they are charged with regulating. "While fair trade founders come from backgrounds in social activism and solidarity," write Renard and Perezgrovas (2007: 147), "some current members of the national initiatives come from very different business-related backgrounds." This is, of course, in addition to formal commercial representation on the NOSB and on the FLO board and committees. A fifth, fairly obvious parallel is that both movements have opted to base their value claims (and attendant price premiums) on third-party certified labels, undergirded by standards and funded by a system of certification fees, now paid by producers in both organics and fair trade. This has positioned both initiatives to be caught up in the steady movement toward harmonization of standards at the national and international levels. A final important similarity is the way standards have been transformed from a mechanism with which to force the internalization of ecological and social costs, into a device that places its imprimatur upon production and trading structures that continue the externalization of those costs (e.g., non-unionized laborers are now used on largescale monocrop plantations of both organic and fair trade products). Just as the practice of input substitution, for example, has allowed large-scale monocrop organic production to become compatible with USDA Organic standards (see Allen and Kovach 2000: 224), so has the "triple whammy" of minimum price stagnation, the elimination of purchase-level benchmarks, and the advent of plantation certification permitted corporate agrifood conglomerates to engage in fair 
trade at token levels without fear of losing control over their sourcing and pricing practices. This bar-lowering has clearly reduced the internalization of costs originally represented by both standards. What remains in each case is, in effect, a single variable: the absence of synthetic agrochemicals in organic, and the provision of a (devalued) minimum purchase price in fair trade.

The differences between the fair trade and organic cases are equally instructive. First, there is the obvious distinction between the state locus of USDA organic standards and the nonstate, nominally civil-society character of fair trade. This has several implications. The public nature of organic standards and the application of the rules by a government agency have left them susceptible to overtly political influences; the multiple instances of direct Congressional interference with the NOSB rules on behalf of particular industries or companies provide ample evidence. On the other hand, the legal framework for organics does lead to fewer seriously credible alternative certification schemes that could compete closely with organic. In fair trade, there are already multiple challengers to the FLO labeling system (e.g. the Ethical Trade Initiative, the Utz Kapeh coffee seal, and other claims of "fairly traded" products that range from genuine to fraudulent). Only public pressure - and the copyrighted nature of the phrase "fair trade certified" - stand in the way of a further proliferation of "faux fair" claims. The difference in the locus of standard-setting and certification is important in other ways as well. It influences the tactics employed by mainstream agrifood firms to capture and weaken the standards and labels. Companies interested in altering the organic standards have used one part of the state against another, bypassing the NOSB to cut back room deals that surface only at the last minute in Congressional riders. Nevertheless, these changes are ultimately a matter of public record and subject to more transparency and scrutiny. With fair trade, in contrast, there is no legal 
regulatory framework, nor a requirement of transparency. Many of the deals that have most compromised the standards (such as removing the 5 percent minimum entry requirement on behalf of Starbucks) are presented as faits accomplis, and can be difficult, if not impossible, to reverse. Corporate participants have also been able to "forum-shop" among the multiple national initiatives to establish precedents regarding licensing; the NIs in the U.S. and U.K. have proven more amenable to their desires than those in other consumer countries.

A second difference regards the structure of third-party certification. The USDA National Organic Program (NOP) accredits a large number of private independent (and also public) certifiers, but since 2002 these entities have not been permitted to uphold more stringent standards; the USDA standards serve as both a "ceiling" and a "floor," removing almost all certifier autonomy. In fair trade, on the other hand, there is a single non-profit, "independent" certification and licensing entity for each country where fair trade goods are sold. These NIs are charged with applying the FLO standards, but in practice there is a good deal of variation and autonomy. The NIs are susceptible to political pressure-whether from corporations or from activist groups engaged in "shaming" tactics - and thus are the site of active contestation over the application of standards. On the other hand, FLO is the sole entity that establishes standards regarding price-setting and the inclusion of new products and production methods, and here the struggle between corporate, producer, and civil-society interests has been at least as intense.

Third, while cooptation has occurred in both organics and fair trade, it differs in both form and degree. Are the processes of capture and standards weakening more advanced in one initiative than the other? The answer seems to be clear: the organic sector (at least in the U.S.) is both subject to more industry influence, and its standards more compromised, than fair tradeat least at the present moment. Guthman observes that "the threat that agribusiness would dilute 
the meanings and practices of organic agriculture has in some respects already been borne out" (2004a: 312). The major battles over organic standards arguably have already been fought and settled, although ongoing skirmishes continue. The governmental nature of the USDA organic standards has tended toward a state of legal finality that is missing from the fair trade arena. For fair trade, some of the most crucial decisions over the direction of the initiative are unfolding as we write, and may be somewhat more subject to renegotiation based on shifting forces. The barn door is partially open, but the horse has yet to make a full escape.

\section{CONCLUSIONS}

We now turn to consider the conclusions that can be drawn from these twin cases of standards weakening and partial capture of governance institutions, and the lessons that other (current or future) agrifood alternative movements might draw from these developments. What could movement-oriented participants have done differently — if anything — to avoid these outcomes and to retain greater integrity in the standards of these systems? How best might future alternative agrifood initiatives, particularly those based on certification, anticipate and avoid some of these traps? And how could they design their initiatives to more effectively guard against cooptation, and prevent — or at least delay — the weakening of standards and the capture of the governance bodies by large-scale players? In an effort to answer these questions, we identify four key issues raised by both cases: the speed of market growth; the scale of participants; the structure of governance institutions; and the nature of movement responses.

The story of both organics and fair trade can be read as a parable of the dangers of rapid growth. Consumer demand in both markets has mushroomed in recent years. However, this "scaling-up" has created a positive feedback loop, driving the processes of institutionalization in 
governance bodies, strengthening the hand of new large corporate players who are best able to meet the new demand, and paving the way for capture.

Many observers stress a distinction between two visions: volume growth at any cost ("growth for growth's sake") versus growth with attention to foundational principles (or "growth to further a vision") (e.g., Erikson 2004). Jonathan Rosenthal, a U.S. fair trade pioneer and cofounder of Equal Exchange, expresses his concern that currently in fair trade, "the ends are justifying the means for too many folks. So they're willing to have a very short timeline about how they look at things, have a real sense of urgency, and be willing to make any compromises to make progress. And specifically that means there's what I'd call this maniacal focus on the corporate sector, and complete disregard for how we could all be working together more effectively. Which in the short run would require a bit of slowing down" (Personal communication, 2005).

Second, the scale of participants matters. In both organics and fair trade, the standards critically failed to include any explicit requirements regarding scale from the outset. Guthman (2004b) documents the tendencies toward intensification in the organic sector, arguing that this will invariably lead to a reduction of the organic premium, thus further disadvantaging small producers. Likewise in fair trade, the certification of agribusiness plantations (in fresh fruit, tea, flowers, and other commodities) directly threatens the income of smaller producers of these same crops. Yet is this anything other than the tendency of capitalism toward consolidation? Allen and Kovach (2000: 224) argue that "[i]n the long run, capitalist dynamics will tend to bring about changes in the standards themselves ... there will be pressure to weaken the standards - to formulate standards more conducive to larger numbers of firms entering the marketplace." In other words, they say, the entry of large players will inevitably lead to cooptation. If this is true, 
then will any safeguards be adequate to protect the organic and fair trade systems (and their smaller producers) against domination and cooptation by the large actors? Perhaps newer alternative agrifood initiatives — particularly those based on certification — should instead design explicit barriers within their rules and standards that simply prevent the entry of big players. Certainly a requirement mandating small-scale production and agroecological diversity in farming systems would help to stave off low-bar mainstream competitors, but such initiatives might consider drawing standards "boundaries" to also include medium-sized agricultural producers who can help the initiative reach critical mass (see Lyson et al. 2008), yet keep the door closed to larger conventional players. How big is too big?

A third set of observations relates to the structure of the institutions that govern these initiatives. Because the pressures for accommodation and capture by large corporate participants can become so intense, the initial design and structure of the bodies that regulate/govern access and certification is crucial, even determinative. To the extent that the principles and visions of the movements' founders can be incorporated into the "DNA" of these bodies - their bylaws, board and committee structures, lines of authority, and funding mechanisms, to name just a few_there exists at least the possibility of safeguarding against cooptation. The issue of the allocation of power, both formal and informal, within such initiatives raises a series of important questions. How will representation be allocated between different participants and constituencies? Can movement pioneers or social-movement constituencies be guaranteed sufficient ongoing representation to ensure that their core principles remain in control of the organization, and how will this power be kept as the coalition becomes more diverse? What is the appropriate role of for-profit commercial entities in these structures? Do the organizations' funding, standard-setting, or decision-making mechanisms set up 
unanticipated tensions between principles of sustainability or social justice, and practices that will eventually come to undermine those values? Future initiatives should consider how to frame a more decentralized, semi-autonomous system that could foster competition among producers for the highest possible standard, rather than a more centralized standard that pushes practices toward the lowest common denominator. Another possibility is prohibitions or disincentives against "mixed operations." This issue is most salient in organics—critics argue that one fatal flaw in USDA Organic standards is the inclusion of farms that produce both organic and conventional produce — but also holds true for fair trade, where transnational firms can enter the lucrative niche while buying only a tiny proportion of their supply at fair trade terms. The inclusion of both kinds of "mixed" operations by definition favors dabblers and large firms with little or no ideological commitment.

The locus of standard-setting also matters. As the case of organics clearly shows, state control over standards-making and certification can be especially problematic; in the U.S. system, it leaves the standards highly vulnerable to political interference on behalf of specific industries and even specific companies. Yet certifications and standards based in civil society can also be vulnerable to pressures from the same actors, albeit through different channels and tactics. Such non-governmental regulatory bodies have their own problems - particularly a lack of transparency, as in the case of FLO and the NIs - but ultimately, they appear to be preferable to state regulation. Future agrifood initiatives would do well, we argue, to steer clear of statebased standards. However, that in itself may not be protection enough, as both state and nonstate standards are subject to "downward harmonization" within the context of neoliberal economic globalization (Mutersbaugh 2005). 
Finally, there is the broader question of what consumers understand about (and how they interpret) these struggles for the soul of organics and fair trade. There have been some highprofile mainstream treatments of these debates regarding organics (e.g., Pollan 2006) and some journalistic coverage of the controversies over corporate fair trade (e.g., Rogers 2004; Goigoi 2008). However, it is unclear to what extent fair trade consumers, for example, could make the jump from "looking for the label" and "voting with their dollars" to activism directed at the very administrators of those labeling systems. What is the potential role of such "citizen-consumers" beyond the constrained realm of the grocery store? Clearly, massive consumer input was vital in keeping any teeth in the original USDA Organic rule, and organizations such as OCA have worked to keep those consumers active, enlisting them in efforts to forestall further wateringdown of organic standards, and pushing corporate licensees to live up to a more meaningful version of fair trade (e.g., Baden-Meyer 2008). Are the broader (and growing) ranks of selfproclaimed "green consumers" potentially a force that could be harnessed by movements to restore or retain the integrity of the system? Can movement advocates educate fair trade and organic consumers about the "real story" of corporate cooptation in these systems without alienating or losing them entirely? One important question for further research in this area would be what effect the public criticisms of cooptation by movement activists (e.g., advocates of "beyond organic" or "deep fair trade") have on consumer perceptions of the organic or fair trade labels.

In his book The Burning Season, author Andrew Revkin quotes the late Brazilian agronomist and activist Jose Lutzinger: "In the environmental movement, our defeats are always final, our victories always provisional. What you save today can still be destroyed tomorrowand so often is" (2004: $x x-x x i)$. The multi-faceted resistance to the cooptation of organics and 
fair trade we describe in this article has indeed been successful at staving off further degradation of standards in some cases, but many of the losses already sustained likely cannot be reversed. Cooptation has transformed fair trade and organics in a broader sense as well. The process of establishing and enforcing standards has de-emphasized or ruled out of bounds the most transformative elements that were present at the inception of both movements: the damning ecological critique of industrial agriculture that guided the organic pioneers, and the urgency of creating truly alternative and socially-just trading relations and institutions that informed the founders of fair trade. The result is the simplification of the operational meaning of both initiatives to a single variable: allowable versus prohibited inputs in organics, and payment of a minimum price in fair trade, the level of which is no longer linked to actual family livelihoods.

On the other hand, while a clear-eyed look at both sets of standards does indicate that the organic and fair trade arenas have been rendered more friendly for conventional food system actors, it is also apparent that the resistance by movement activists to the evisceration of standards has kept them far stronger than they otherwise would have been. The success of these alternatives - albeit in weaker form than their founders intended — has had a significant impact on agrifood systems: the single-variable issues they now represent have at least become part of mainstream public discourse. Indeed, this is one effective argument for continuing efforts at the margins to strengthen and/or protect the existing standards, in addition to creating even newer alternatives. Beyond this, advocates for socially-just and ecologically sound food systems can aim to learn from the creeping defeats of previous efforts, and design future structures to build upon their ever-contingent victories. 


\section{REFERENCES}

Allen, Patricia and Martin Kovach. 2000. The capitalist composition of organic: The potential of markets in fulfilling the promise of organic agriculture. Agriculture and Human Values 17(3): 221-232.

Alpert, Bill. 2007. Do-gooders who could do better. Barron's, November 12. http://online.barrons.com/article/SB119465909085388805.html?mod=googlenews barro ns. Accessed June 30, 2008.

Bacon, Christopher, CAFENICA, and Coordinadora Latinoamericana y del Caribe de Pequeños Productores de Comercio Justo (CLAC). 2006. Estudio de costos y propuesta de precios para sostener el café, las familias productores y organizaciones certificadas por comercio justo en america latina y el caribe.

Baden-Meyer, Alexis. 2008. Testimony from the OCA to USDA on preserving organic standards and expanding organics. http://www.organicconsumers.org/articles/article_12488.cfm. Accessed July 3, 2008.

Barrientos, Stephanie, Michael E. Conroy and Elaine Jones. 2007. Northern social movements and fair trade. In Fair trade: The challenges of confronting globalization, eds. Laura T. Raynolds, Douglas Murray and John Wilkinson, 51-62. New York: Routledge.

Bastian, Hope. 2006. "Keeping fair trade fair in Mexico." NACLA Report on the Americas 39(6): 6.

Brown, Michael Barratt. 1993. Fair trade: Reform and realities in the international trading system. London, Zed.

Broydo, Laura. 1998. Organic engineering. Mother Jones, May/June.

Buck, Daniel, Christina Getz, and Julie Guthman. 1997. From farm to table: The organic vegetable commodity chain of northern California. Sociologia Ruralis 37(1): 3-20.

Campbell, David. 2001. Conviction seeking efficacy: Sustainable agriculture and the politics of co-optation. Agriculture and Human Values 18(4): 353-363.

Clark, Merrill. 2007. Consumers, tell USDA to protect organic food standards. South Bend Tribune, August 21:

http://www.southbendtribune.com/apps/pbcs.dll/article?AID=/20070821/Opinion/708210 428/1064/Opinion. Accessed June 28, 2008.

Cone, Marla. 2008. Irradiation could curb food illnesses. Los Angeles Times, April 11. http://articles.latimes.com/2008/apr/11/nation/na-greens11. Accessed June 29, 2008.

Conner, David. 2004. Beyond organic: Information provision for sustainable agriculture in a changing market. Journal of Food Distribution Research 35 (1): 34-39.

Cornucopia Institute. 2007. USDA cracking down on 'organic' factory farms. http://www.cornucopia.org/index.php/usda-cracking-down-on-organic-factory-farms/. Accessed June 2, 2008.

Cummins, Ronnie. 2002. Is USDA organic grade B organic? http://www.organicconsumers.org/organic/gradeb092902.cfm. Accessed May 23, 2008.

Cummins, Ronnie and Adam Eidinger. 2006. USDA attempts to pack organic standards board with corporate agribusiness reps. http://www.organicconsumers.org/articles/article_3526.cfm. Accessed July 2, 2008.

Dal Bó, Ernesto. 2006. "Regulatory capture: A review." Oxford Review of Economic Policy 22(2): 203-225. 
Delind, Laura B. 2000. Transforming organic agriculture into industrial organic products: Reconsidering national organic standards. Human Organization 59 (2): 198-208.

DiMaggio, Paul J. and Walter W. Powell. 1983. The iron cage revisited: institutional isomorphism and collective rationality in organizational fields. American Sociological Review, 48(2): 147-160

DuPuis, Melanie. and Sean Gillon. 2007. The dynamics of alternative/sustainable economies: modes of governance as everyday forms of collaboration. Paper presented at the Yale Agrarian Studies Colloquium Series. New Haven, CT. September 7. http://www.yale.edu/agrarianstudies/papers/01dupuis.pdf. Accessed June 29, 2008.

Eden Foods. 2006. Why Eden foods chooses not to use the USDA seal. Press Release, June 19: http://www.edenfoods.com/articles/view.php?articles id=78. Accessed June 2, 2008.

Erickson, Gary. 2004. Raising the bar: integrity and passion in life and business: The story of Clif Bar \& Co. San Francisco: Jossey-Bass.

Fantle, Will. 2008. Cornucopia Institute's complaints expose outlaw factory farms. Cooperative Grocer 134.

Fetter, T. Robert and Julie A. Caswell. 2002. Variation in organic standards prior to the National Organic Program. American Journal of Alternative Agriculture 17(2): 55-74.

Fairtrade Labelling Organizations International (FLO). 2007. Global fairtrade sales increase by $40 \%$, benefiting 1.4 million farmers worldwide. http://www.fairtrade.net/single_view.html?cHash=b3703de592\&tx_ttnews\%5BbackPid $\% 5 \mathrm{D}=168 \&$ tx_ttnews $\% 5 \mathrm{Btt}$ news $\% 5 \mathrm{D}=26$. Accessed July 29, 2008.

Food \& Drink Weekly. 2003. OTA launches campaign to roll back 'redefinition' of organic. March 17.

Fridell, Gavin. 2007. Fair trade coffee: The prospects and pitfalls of market-driven social justice. Toronto: University of Toronto Press.

---. 2003. Fair trade and the international moral economy: within and against the market. CERLAC Working Paper Series. Toronto, Canada.

Fridell, Mara, Ian Hudson, and Mark Hudson. 2008. With friends like these: the corporate response to fair trade. Review of Radical Political Economy 40(1): 8-34.

Fromartz, Samuel. 2006. Organic, Inc.: Natural foods and how they grew. Orlando, FL: Harcourt.

Gamson, Howard. 1968. Power and Discontent. Homewood, IL: Dorsey Press.

---. 1975. The Strategy of Social Protest. Homewood, IL: Dorsey Press.

Global Exchange. 2007. 100\% fair trade companies. http://www.globalexchange.org/campaigns/fairtrade/coffee/retailers.html. Accessed July 29, 2008.

Goigoi, Palavi. 2008. Is Fair Trade Becoming 'Fair Trade Lite'? Business Week, June 18.

Goodman, David and Michael Goodman. 2007. "Localism, livelihoods and the 'post-organic': Changing perspectives on alternative food networks in the United States." In eds. Damian Maye, Lewis Holloway, and Moya Kneafsey, Alternative food geographies: representation and practice, 23-28. Oxford, UK: Elsevier Science.

Guthman, Julie. 2004a. Agrarian dreams: The paradox of organic farming in california. Berkeley: University of California Press.

---. 2004b. The trouble with 'organic lite' in California: A rejoinder to the 'conventionalisation' debate. Sociologia Ruralis 44 (3): 301-316. 
Hatamiya, Lon S. 1997. Proposed organic standards. Informational Memorandum for the Deputy Secretary, USDA, May 1.

http://www.motherjones.com/news/outfront/1998/05/usda_doc1.html.

Howard, Phil. 2008. Organic Industry Structure.

http://www.msu.edu/ howardp/organicindustry.html. Accessed July 21, 2008.

Howard, Philip and Patricia Allen. 2006. Beyond organic: Consumer interest in new labelling schemes in the central coast of California. International Journal of Consumer Studies 30(5): 439-451.

Ikerd, John. 1999. Organic agriculture faces the specialisation of production systems; specialized systems and the economical stakes. Colloques de l'INRA

Ingram, Mrill and Helen Ingram. 2005. Creating Credible Edibles: The Organic Agriculture Movement and the Emergence of U.S. Federal Organic Standards. In eds. D. Meyer, V. Jenness, and H. Ingram, Routing the opposition: Social movements, public policy and democracy, 121-148. Minneapolis: University of Minnesota Press.

Jaffee, Daniel. 2007. Brewing justice: Fair trade coffee, sustainability, and survival. Berkeley: University of California Press.

Jaffee, Daniel, Jack R. Kloppenburg, Jr., and Mario B. Monroy. 2004. Bringing the "moral charge" home: Fair trade within the north and within the south. Rural Sociology 69(2): 169-196.

Johnson, Gene. 2007. Lawsuits allege milk wasn't organic. Associated Press, December 13. http://www.commondreams.org/archive/2007/12/13/5807/. Accessed June 2, 2008.

Kavilanz, Parija B. 2008. The high price of going 'organic'. CNNMoney, April 23: http://money.cnn.com/2008/04/23/news/companies/organics_backlash/index.htm?postver sion=2008042314. Accessed June 29, 2008.

Laffont, Jean-Jacques and Jean Tirole. 1991. The politics of government decision-making: A theory of regulatory capture. Quarterly Journal of Economics: 1089-1127.

Lavigne, Paula. 2006. Is organic food the real deal? The Dallas Morning News, July 17: http://www.dallasnews.com/sharedcontent/dws/dn/latestnews/stories/071606dnccoorgani cs.19c550e.html. Accessed June 2, 2008.

Lockie, Stewart, Kristen Lyons, Geoffrey Lawrence, and Darrin Halpin. 2006. Going organic: Mobilising networks for environmentally responsible food production. Cambridge, MA: CABI.

Mansfield, Becky. 2004. Organic views of nature: The debate over organic certification for aquatic animals. Sociologia Ruralis 44 (2): 216-232.

Margulis, Charles. 2006. Organic milk market threatened by lack of adequate pasture requirement. http://www.centerforfoodsafety.org/press_release4_12_2006.cfm. Accessed July 1, 2008.

McKinney, Matt. 2007. Was Target's organic milk just regular? Minneapolis Star Tribune, September 29.

Mutersbaugh, Tad. 2005. Fighting standards with standards: Harmonization, rents, and social accountability in certified agrofood networks. Environment and Planning A 37(11): 2033-2051.

Myers, Steve. 2008. The organic factor: Does organic certification equate to better quality production? Natural Products Insider, January 2.

Nesmith, Jeff. 2002. Georgians push for looser use of 'organic' for chicken. Atlanta JournalConstitution, June 5. 
Ness, Carol. 2004. Organic food fight: Outcry over rule changes that allow more pesticides, hormones. San Francisco Chronicle, May 22: A-1.

National Institute for Animal Agriculture (NIAA). 2007. 2007-2008 NIAA Resolutions and Position Statements: Poultry Health. http://www.animalagriculture.org/aboutniaa/Resolutions/POULTRY/Poultry\%20Health \%202007-2008.pdf. Accessed June 28, 2008.

Organic Business News. 2006. Heinze quits NOSB after criticism. February.

Organic Consumers Association. 2008. Tell Starbucks We Want Fair Trade, Not Greenwashing. Organic Bytes 139. http://www.organicconsumers.org/bytes/ob139.cfm. Accessed July 30, 2008.

Organic Foods Production Act of 1990. Public Law 701-624: 1990; Title 21, U.S. 1990 Farm Bill.

Organic Trade Association (OTA). 2007. The Organic Trade Association 2007 manufacturer survey overview. http://www.ota.com/pics/documents/2007ExecutiveSummary.pdf. Accessed June 28, 2008.

---. 2006. The Organic Trade Association 2006 Manufacturer Survey Overview. http://www.ota.com/pics/documents/short\%20overview\%20MMS.pdf Accessed June 2, 2008.

Pollan, Michael. 2006. The omnivore's dilemma: A natural history of four meals. New York: Penguin Press.

Progressive Grocer. 2008. Health \& wellness sales topped \$102 billion in '07: Study, July 7: http://www.progressivegrocer.com/progressivegrocer/content display/features/healthwellness/e3i9a3650f4bf2de2993f3e716f18be32e4?imw=Y. Accessed July 21, 2008.

Raynolds, Laura T. 2007. Fair trade bananas: broadening the movement and market in the united states. In Fair trade: The challenges of confronting globalization, eds. Laura T. Raynolds, Douglas Murray and John Wilkinson, 63-82. New York: Routledge.

---. 2000. "Re-Embedding Global Agriculture: The International Organic and Fair Trade Movements." Agriculture and Human Values 17(3): 297-309.

Raynolds, Laura T. and John Wilkinson. 2007. Fair Trade in the Agriculture and Food Sector: Analytical Dimensions. In Fair trade: The challenges of confronting globalization, eds. Laura T. Raynolds, Douglas Murray and John Wilkinson, 33-47. New York: Routledge.

Raynolds, Laura T., Douglas Murray, and Andrew Heller. 2007. Regulating sustainability in the coffee sector: A comparative analysis of third-party environmental and social certification initiatives. Agriculture and Human Values 24: 147-163.

Reed, D. (Forthcoming). What do corporations have to do with fair trade? Positive and normative analysis from a value chain perspective. Journal of Business Ethics.

Renard, Marie-Christine. 2006. Recomposición de la gobernancia en el comercio justo: Entre la construcción de la calidad y la disputa por su definición. Paper presented at Coloquio ALTER. October 2006, Baeza, Jaén, Spain.

---. 2005. "Quality certification, regulation and power in fair trade." Journal of Rural Studies 21(4): 419-431.

Renard, Marie-Christine and Victor Perezgrovas. 2007. Fair trade coffee in mexico: At the center of the debates. In Fair trade: The challenges of confronting globalization, eds. Laura T. Raynolds, Douglas Murray and John Wilkinson, 138-156. New York: Routledge.

Revkin, Andrew. 2004. The burning season: The murder of Chico Mendes and the fight for the Amazon. Washington, D.C.: Island Press. 
Rogers, Tim. 2004. Small coffee brewers try to redefine fair trade. Christian Science Monitor, April 13.

Ronald, Pamela. 2008. The new organic. The Boston Globe, March 16.

Scowcroft, Bob. 2006. The organic conversation begins anew (again). Greenmoney Journal $15(2)$.

Selznick, Philip. 1949 (1966). TVA and the grass roots. New York: Harper.

Shulman, S.W. 2003. An experiment in digital government at the United States national organic program. Agriculture and Human Values 20 (3): 253-265.

Starbucks Coffee. 2008. Fiscal 2007 Corporate Social Responsibility Annual Report. http://www.starbucks.com/aboutus/csr.asp. Accessed June 7.

Stigler, George. 1971. The theory of economic regulation. Bell Journal of Economics and Management Science 2: 3-21.

Sung, A. 2008. Upstream battle. Supermarket News, February 25. http://supermarketnews.com/meat/upstream battle 4/. Accessed May 23, 2008.

Thomas A. Lyson, G. W. Stevenson, R. Welsh (eds.) 2008. Food and the mid-level farm: Renewing an agriculture of the middle. Cambridge: MIT Press.

Transfair USA. 2007. FLO International raises fairtrade price for coffee farmers. Press Release. http://www.transfairusa.org/content/about/pr/pr_071214.php. Accessed July 30, 2008.

Tschang, Chi-Chu. 2007. Organic, with pesticides. Business Week, July 30.

USDA. 2008. National Organic Program: National Organic Standards Board. http://www.ams.usda.gov/NOSB/index.htm. Accessed July 1, 2008.

Vos, T. 2000. Visions of the middle landscape: Organic farming and the politics of nature. Agriculture and Human Values 17 (3): 245-256.

Weiss, Rick. 2004. Engineered DNA found in crop seed. Washington Post, February 24: A02.

Wilson, Scott J. 2007a. Foodmakers in limbo over 'organic' labeling. Los Angeles Times, June 14. http://articles.latimes.com/2007/jun/14/business/fi-organic14. Accessed June 28, 2008.

---. 2007b. Nonorganic ingredients get tentative OK. Los Angeles Times, June 23. http://articles.latimes.com/2007/jun/23/business/fi-organic23. Accessed June 2, 2008.

Wolcott, Jennifer. 2002. An end to organic confusion? The Christian Science Monitor, October 16. http://www.csmonitor.com/2002/1016/p15s02-lifo.html. Accessed June 2, 2008. 